\section{SAAAA \\ JOURNAL}

Journal of Archaeology and Fine Arts in Southeast

Asia

Published by the SEAMEO Regional Centre for Archaeology and Fine Arts (SPAFA)

\title{
The diversity of contemporary Christianity in Southeast Asia
}

Jayeel Cornelio

Director, Development Studies Program

Ateneo de Manila University

Visiting Professor, Divinity School of Chung Chi College

The Chinese University of Hong Kong jcornelio@ateneo.edu

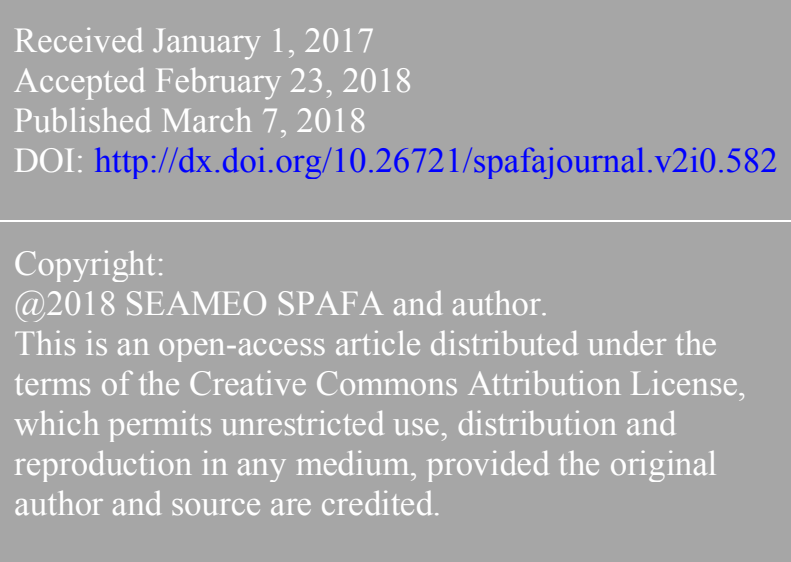

\begin{abstract}
This article is concerned with the diverse forms of Christianity as the religion spreads around Southeast Asia. Although growth and expansion characterize much of Christianity's fortunes, no unifying trend is readily discernible. Four trends are identified in this article: popular religion, megachurches, the global church, and the struggling church. The article draws from different cases around the region to illustrate the importance of these developments.
\end{abstract}

It in this manner that the article complicates the narrative that Christianity is moving to the Global South. The narrative often presents Christianity as a religion at war with itself insofar as geographic tensions are concerned. In contrast to its counterpart in the West, Christianity in the region is depicted as strict, fundamentalist, and often Charismatic in orientation. To view Christianity in Southeast Asia as a homogenous entity disregards issues at stake for its many denominations. Some of these concerns include different political regimes and uneven levels of economic development. This paper was delivered as an opening lecture at the workshop on Christian art in Southeast Asia, organized by SEAMEO SPAFA in the Philippines in March 2016.

Keywords: Christianity, Southeast Asia, World Christianity, Global South, Religious Change 
When observers narrate the movement of Christianity to the Global South, they refer often implicitly - to its success in Africa and Latin America. The proportion of Europeans among the world's Christians declined from $66.3 \%$ in 1910 to $25.9 \%$ in 2010 (Pew Research 2011). But in the same period, the population of Christians in Africa and Latin America increased dramatically. Indeed among the top ten countries with the largest number of Christians are Brazil, Mexico, Nigeria, DR Congo, and Ethiopia. In these countries Christianity has witnessed spectacular conversions and the emergence of new movements and indigenous churches.

Southeast Asia, an emerging economic region, is typically mentioned in this narrative of Christianity's turn to the Global South. But most of the time the narrative refers only to the Philippines and Timor Leste. After all, these are the only two countries in the region whose populations are predominantly Catholic. Christians constitute more than $90 \%$ of the populations in the Philippines and in Timor Leste respectively. But their brethren in most of the other countries in the region constitute only less than $10 \%$ of their respective populations (Pew Research 2014).

It is for this reason that the region's inclusion in the Global South narrative must be problematized. The account often presents Christianity as a religion at war with itself at least insofar as geographic tensions are concerned. Christian churches in the Global South are depicted as strict, fundamentalist, and often Charismatic in orientation (Jenkins 2006; Jenkins 2011). Their adherents often object to the progressive theology and practices of their counterparts in the West, who have, for example, ordained openly gay bishops or questioned the historicity of the Scriptures. To view Christianity in Southeast Asia as a homogenous entity disregards issues at stake for its many denominations. The region has different political regimes and uneven levels of economic development, among other concerns (Bautista and Lim 2012).

This article spells out the different manifestations of Christianity's diversity in Southeast Asia. No unifying trend is readily discernible although growth and expansion characterize much of Christianity's fortunes. The task of this article is to identify what trends might matter today and in the near future. The list, of course, is not exhaustive and cannot be contained in a short article such as this. The point nevertheless is to complicate the narrative about the homogeneity of Christianity in the region. I draw from different cases around the region to illustrate the importance of these manifestations. Elsewhere I have argued a similar point about the fortunes of religion among the youth in East and Southeast Asia (Cornelio 2015).

The discussion in this chapter is sociological in orientation, situating the trends in broader social changes that are taking shape in Southeast Asia. In some cases, explanations have been derived from the religious actors themselves to make sense of these trends. In other words, these trends primarily refer to the experiences of different Christians in the region. They can also influence different denominations. This approach is analytically helpful in assessing Christianity's future trajectories in relation to its contemporary challenges (Cornelio 2018a). It differs from a missiological approach, which gives emphasis to trends that matter to missionaries themselves and the effectiveness of their initiatives. Patterns of accommodation and inculturation, for example, would be of interest in this regard. 
Christianity, as it continues to expand under different regimes in the region, will develop its own theologies and practices with implications on art and aesthetics. ${ }^{1}$ Religious metaphors, for example, are to be drawn from their immediate experiences. Christianity in this sense is a living phenomenon in the region as it is elsewhere in the world. Finally, it is worth noting that my use of Christianity in this article embraces "ecclesial diversity" which includes different denominations, movements, and even indigenous churches (Phan 2011a: 3). Christianity in the region must be taken in its plural form (i.e. Christianities) since its churches have distinct histories informed by colonial, missiological, national, and local concerns. This is not to say though that they are isolated. These religious groups are also intertwined with global networks that allow for the circulation and appropriation of contemporary practices, preaching, music, and other expressions of the faith (Cox 2006).

\section{Popular Piety}

I begin with popular religion, which broadly refers to local religious expressions in terms of beliefs and practices. Conceptually it stands in contrast to the official promulgations of religious leaders or experts (Ammerman 2007). As they take shape among non-experts, popular forms of piety are directly informed by people's local experiences and interpretations of Christianity. It can cover a wide array of religious experiences such as healing practices, folk beliefs about spirits, feasts dedicated to saints, Bible study groups, Marian piety, and Charismatic worship.

To illustrate, Catholicism in the Philippines is often portrayed in the media in terms of its adherents' devotional practices. International coverage of the religion in the country is typically interested in spectacular events that punctuate the Christian calendar. Millions of devotees, for example, participate in the procession of the Black Nazarene at the start of every year. During Holy Week, real-life crucifixions take place in Luzon not simply to re-enact the passion of Christ but to express religious commitment. Devotions also surround particular icons like the Virgin Mary or the Santo Niño (Bautista and Bräunlein 2014; Sapitula 2014). Given the country's long history under Spain, Catholicism has permeated many aspects of social life from individual rites of passage to village festivals.

Scholarship on popular piety in the Philippines has been approached differently over the past decades (Cornelio 2014a). It is one of the most prominent aspects of Filipino Catholicism in the literature. ${ }^{2}$ There are at least three ways in which popular religion has been understood.

First, for earlier social scientists, popular piety was seen as a problem of conversion and deepening of the faith. Split-level Christianity, a concept that referred to many

\footnotetext{
${ }^{1}$ I mention this point because this paper was presented at the workshop on Christian art in Southeast Asia, organized by SEAMEO SPAFA in the Philippines in March 2016. The participants of the workshop were mostly scholars in art studies and practitioners.

${ }^{2}$ See the special issue of Philippine Studies: Historical and Ethnographic Viewpoints (2014) dedicated to the study of Filipino Catholicism.
} 
aspects of religious life, is primarily concerned with the seeming inconsistencies between one's beliefs and actions (Bulatao 1966). At one level it is applied to think of the moral inconsistencies among Catholic adherents. But at another level, it is also applied to refer to folk Catholicism, which priests and missionaries considered problematic because of their "pagan patterns of beliefs and practices" (Gorospe 1966: 210). In this light, many forms of popular piety are evaluated against standards of religious and theological consistency. Religious experts, for example, typically label the massive procession dedicated to the Black Nazarene in Manila as an example of fanaticism because of its rowdiness.

Second, anthropologists in the latter part of the 20th century did not subscribe to this view. To them, the seeming contradictions are inherent given that everyday religion is the space where pre-Hispanic beliefs could linger unnoticed. Saints, for example, may occupy a prominent role in the life of a rural village. But these roles, say in the agricultural cycle, are effectively the same ones that local deities took on before the Spaniards arrived with the Christian gospel. Everyday Catholicism in this sense is a continuation of polytheistic religion in the Philippines (Macdonald 2004). Many other anthropologists were also interested in what the seeming contradictions meant to the religious individual. Whereas missionaries were taken aback by how locals could appeal to both their Catholic priests and local shamans, anthropologists saw them as rational decisions. Locals, for example, may see these two entities as on par with each other because of their intermediary role in seeking divine intervention (Jocano 1965).

Finally, scholarship on popular religion has been taking a different shape in recent years. Consistent with the growing interest in religious identity in the social sciences, scholars of popular religion in the Philippines are giving attention to what beliefs and practices mean to locals. This is characterized as the turn to everyday authenticity (Cornelio 2014a). In this approach, the seeming misalignment between individual practices and official church doctrines is still present but no longer evaluated as theologically inconsistent. For example, the religious understanding of Catholic devotees who crucify themselves during Holy Week is considered inadequate by some observers. But for scholars like Bräunlein (2012: 385), many of these devotees consider themselves "100 percent Catholic." In the same manner, Passion rituals during Holy Week, rife with stories of suffering surrounding Christ, could be a way of making the Christian narrative intimate to religious actors (Francisco 2011). Finally, in my own work on Catholic youth, I noticed that many of them, while disagreeing with many doctrines or practices of the Catholic Church, are quick to point out that what they do to express their faith makes it more meaningful. They are, for example, active in volunteer work or outreach activities of their respective Catholic organizations. That right living is more important than right believing exemplifies their reflexive spirituality (Cornelio 2014b; Cornelio 2016). The point that these scholars make is that religion is not simply a received category. It is reinterpreted in ways that are meaningful to the individual, thus underscoring the reflexive role of the self. 


\section{The Megachurch}

The diversity of Christianity in Southeast Asia is also demonstrated by the prominence of megachurches. Megachurches, the memberships of which go beyond 1000, are immediately perceived as Western forms of Christianity given their strong evangelical and contemporary feel. Their pastors and singers appear even on mainstream television. The most prominent megachurches are in fact in the US and Australia (Ellingson 2010; Miller 1997). Many of them are embedded in global networks of evangelical megachurches, which afford them efficient circulation of the books, messages, and music they produce. A typical service in any of these megachurches can then employ the same repertoire of songs, jargons, and narratives.

Megachurches have become prominent especially in urban parts of Southeast Asia as well. Singapore, Jakarta, Bangkok, and Manila have their own megachurches. That they primarily cater for the aspirational middle class is well documented (Chong 2018). In Singapore, New Creation Church and City Harvest have the biggest congregations. They typically attract young people who are English-educated and of Chinese descent, individuals brought up in the competitive economic environment of Singapore (Tong 2008). These churches, known to celebrate prosperity, provide them with the religious and innerworldly narratives to frame their aspirations. Indeed, being successful in the marketplace and one's career is a virtue that is often justified in terms of the goodness of God.

In this sense, megachurches have internalized the business ethos of growth and influence. Apart from articulating their success in terms of numerical expansion, they are involved too in constructing massive buildings. These constructions, of course, are justified using a missiological language (Yip and Ainsworth 2015). In the Philippines, Every Nation has recently expanded its headquarters in the new central business district on the premise that it aims to train more missionaries from other parts of Asia (Cornelio 2017). I will revisit this point in the next section.

In the spirit of growth and influence, success is tied to a dominion theology that calls on its followers to be influential in different spheres of society. This is why megachurches attempt to be politically involved. Some of them can lobby particular policies that advance their moral worldviews while others actively field their own candidates in elections. Their actions depend on their respective legal and political restrictions. Their political involvement, of course, is not unproblematic for the greater public sphere. In other words, their religious nationalism can be repulsive to non-members and others who do not share their theological convictions. Some congregations in Singapore have been embroiled in controversial issues such as sexual morality and the entry of gambling via integrated resorts in the past decade (Chong 2011b; Chong 2011a). In the Philippines, the Jesus is Lord Church fielded its senior pastor as candidate for president in several elections. Brother Eddie Villanueva believed that he was called by God to be a transformative leader. This move caused divisions within the Evangelical world in the country (Cornelio 2018b).

It is important to note that not all megachurches are decidedly Pentecostal or middleclass. A prominent congregation in Indonesia is Rev. Stephen Tong's Reformed 
Evangelical Church of Indonesia (RECI). Rev. Tong is touted to be the Billy Graham of the East. While the most prominent megachurches in Southeast Asia are Charismatic or Pentecostal, RECI's theology is Calvinist and its liturgical worship quite traditional (Hoon 2015). Jesus is Lord, one of the fastest-growing indigenous Evangelical churches in the world, primarily attracts the working class in the Philippines. Even its international outreach churches also attract Filipina domestic workers.

\section{The Global Church}

The rising affluence of Southeast Asia as a region has witnessed the emergence of megachurches catered primarily (but not only) for the middle class. But as a region, Southeast Asia is also playing an important role in global political configurations. The Association of Southeast Asian Nations, for example, is now an important dialogue partner for such countries as China, Japan, and the US in maintaining security and global trade. Paralleling this development is that many countries in Southeast Asia serve as important locations or conduits for international Christian movements. The region's megachurches, as mentioned above, are embedded in global networks that allow for the circulation of their music, literature, and theology. In this section I highlight how churches in the region are performing other important tasks for the expansion of Christianity at the regional and global level.

First, some countries in the region serve as headquarters of Christian movements and organizations. Some of these organizations are in fact indigenous as well. Apart from the churches mentioned above, there are also other prominent examples such as Hope of God in Bangkok, Iglesia ni Cristo (INC, Church of Christ) in Manila, and even the Anglican Church in Singapore. Hope of God, a movement that originated in Bangkok, is one of the fastest-growing evangelical churches in Thailand. It has also planted mission churches in Southeast Asia and other parts of the world. Founded in 1914, INC is an indigenous Christian church in the Philippines. It rejects mainstream Trinitarian doctrine and believes that its founder, Brother Felix Manalo, is the last angel to come from the east prophesied in the Scriptures. It has opened outreach churches all over the world as well. The Anglican Church in Singapore, part of the wider Anglican Communion, has planted and supported smaller Anglican congregations in Southeast Asia. But more importantly, it has taken on a prominent role among churches of the Anglican Communion in the Global South in rejecting what they consider the capitulations of their counterparts in the West to moral and religious shifts. Some of these issues include same-sex marriage and the ordination of gay clergy.

These organizations have different theological persuasions and may in fact contradict each other. Nevertheless, they actively train and send out missionaries to different parts of the region and the world. In fact, they also have their own seminaries and training centres. Furthermore, worth highlighting is the role of these churches in delivering welfare and humanitarian assistance not just in their respective countries but elsewhere too.

Second, apart from their global outreach, many churches in Southeast Asia are playing a big role in religious worlding. Religious worlding refers broadly to the 
ethos that renders postcolonial cities as new centres of religious significance. For example, many countries in the region, as mentioned above, have taken a leadership role in planting and supporting new congregations around the world. This is an important shift in the consciousness of Christians in former colonies of empires affiliated with Catholic and Protestant missionaries. But in my own recent scholarship, I have framed religious worlding in terms of physical constructions initiated by influential Christian churches in the Philippines (Cornelio 2017). A common denominator among these constructions is that they were built as grandiose projects that recreate themselves as new centres of global Christianity. Some of them have exceeded global standards. INC, for example, has inaugurated the Philippine Arena, the biggest indoor stadium in the world that can accommodate at least 50,000 spectators. It has already been used for concerts and other big events. But INC also uses it for its major religious gatherings. It is situated in the midst of Ciudad de Victoria (City of Victory) that will also be home to residences, hospitals, and campuses affiliated with INC. The entire complex was inaugurated on the 100th anniversary of INC in 2014 as a marker of God's blessing upon the church. Every Nation, with counterpart headquarters in Europe and the US, has recently expanded its headquarters. It is located right in the middle of the new central business district, right next to an international school and a stretch of commercial, residential, and corporate buildings. Every Nation, the very name of which denotes its global aspirations, wants its headquarters in Manila to be a centre of training and a launching pad of new missionaries to different countries in Asia. Finally, there is also E1 Shaddai, the well-known Catholic Charismatic group founded by Brother Mike Velarde (Wiegele 2005). In the previous decades it used to hold its massive services in open grounds around Manila. But recently it built the International House of Prayer, which is believed to be the biggest place of worship in Asia. It can seat 25,000 attendees and its surrounding grounds can accommodate even more.

Given these two important modes of being global, Southeast Asia becomes a breeding ground for new and influential ways of doing Christianity. Put differently, these religious organizations reflect the global aspirations of many contemporary Christians, sacralizing Southeast Asia in effect. I need to note, however, that this development, of course, is not entirely new. In the 1940s, Far East Broadcasting Corporation was set up in Manila to broadcast evangelistic messages to the "Unreached People Groups" of peninsular Southeast Asia (Ngo 2009: 145). While the global ethos of Christian churches in Southeast Asia today is a continuation of this evangelistic fervour, it is also important that many of them started out as local or indigenous congregations.

\section{The Struggling Church}

The success of Christianity in the region is clearly exemplified by the fortunes of megachurches and the global ambitions of different movements. But the picture is not comprehensive enough without giving attention to the other reality that characterizes the tapestry of Christianity in Southeast Asia. The realities of suffering for many Christians need to be considered in order to temper the typical celebratory remarks about the faith's expansion. Simply put, they are important because they render problematic the successes of Christianity presented above. That these issues are tackled last in this chapter is thus also a critical reflection on the response of 
Christianity as a whole. As Koo (2008) points out, the presence of affluent churches in the midst of suffering makes witnessing a potentially awkward endeavour.

The struggles of the church refer to the difficulties Christians are faced with on various fronts: poverty, persecution, conflict, and new modes of suffering brought about by climate change. In spite of the region's increasing affluence, many Southeast Asian economies are still generally poor. Christian churches and humanitarian organizations have to contend with issues of homelessness, unemployment, and hunger. Around the region, poor women and children are trafficked and Christian organizations seek to address injustices done against them (Sison-Arroyo 2008). In terms of persecution, cases have been reported in different parts of peninsular Southeast Asia like Myanmar and Vietnam where Christianity remains a minority religion. Although there can be various reasons for persecution, many of these cases are associated with ethnic strife as well. In other words, ethnic conflicts are exacerbated by religious differences. And for those affected, conflicts deepen conditions of poverty. In some cases, the marginalization of Christians is not necessarily violent. But given that other dominant religions are privileged, as in the case of Islam in Malaysia, the activities of Christians in media, education, and the wider public sphere are limited (Goh 2005). Finally, suffering has started to take on a new shape in recent years. Weather patterns have become more unpredictable especially for the Philippines, which encounters more than twenty typhoons every year. Typhoon Haiyan, one of the strongest typhoons ever recorded, hit the eastern part of the country in late 2013, leaving thousands of dead bodies in its path. The most affected communities were coastal villages inhabited by fisher folk and the poor. When Pope Francis visited the Philippines in early 2015, he made it a point to go to the province. That he celebrated the Mass in the midst of the rain was a powerful reminder of the tragedy to the Catholic faithful there.

The struggles of Christians need to be recognized for they are deeply connected to their religious narratives and piety. This connection has already been brought up above but it is worth mentioning again that the lingering relevance of popular religion has evident relations with local contexts of suffering. Reaching for the icon of the Black Nazarene during its procession to wipe it with a piece of cloth is an attempt to access its miraculous healing for illnesses among poor devotees and their relatives. This is why the Christ that permeates the "liberative efforts and redemptive communities of the suffering peoples" mirrors the struggle for justice and freedom (Orevillo-Montenegro 2006: 49). The same may be said of popular devotions surrounding icons such as the Santo Niño, the Virgin Mary, and other saints. But these popular devotions may also be about the aspiration for the holy, in the sense that the physical touch is believed to transmit the attributes of divinity. In this light, the desire to get close to God "is to participate in the power and holiness of God" (Agong et al. 2008: 115).

\section{Conclusion}

This article has been concerned with the diverse forms and issues of Christianity as the religion spreads around Southeast Asia. Four were identified but the list is not exhaustive: popular religion, megachurches, the global church, and the struggling 
church. Recognizing the diverse manifestations of Christianity in the region is analytically significant on several levels.

First, the different trends spelled out above show the fortunes of Christianity in the region (Goh 2005). The point is that there is no one grand narrative even if some commentators might celebrate the expansion of the religion on different fronts. In some contexts churches are struggling. In others they are triumphalist. The local theologies and practices are necessarily informed by these churches' engagements with local realities. Christian organizations especially in peninsular Southeast Asia are persecuted for suspicion that they are imported from the West and are inherently anti-establishment. But among the affluent middle class in Singapore, Indonesia, and the Philippines, some churches are influential in politics.

Second, to recognize the diverse trajectories of Christianity in Southeast Asia is not simply an intellectual enterprise. It necessarily recognizes the role religion can play towards peacebuilding and addressing the problems of poverty and other forms of suffering. This is one realization that future studies should explore. The experiences of suffering in some contexts and the contributions of influential churches to welfare in the region are instructive (Wanak 2008). Their narratives contest the view that strife and conflicts are inevitably tied to the diverse religious identities in the region. Phan (2011a: 5) considers this a "hopeful lesson" for Christianity.

Finally, in the interest of the workshop where this paper was first presented, Christianity's diverse fortunes in the region have implications not just on theologies but also aesthetics. Art and music can capture the metaphors and experiences that matter to Christians in the region. Artists, for example, have recast Jesus "as the heartbeat of the popular culture struggling for space to breathe, for dignity, for a meaning that overcomes death" (Prior 2011: 68). And given the ethnic diversities in the region, Christian art and music do not have to mirror only local struggles. In the spirit of dialogue, they can also become instruments for reconciliation, peace, and justice (Phan 2011b). Although they are often pitted against each other, triumphalist and struggling churches have their parts to play for the sake of reconciliation.

\section{References}

Agong, B, Capaque, G, Gener, T, Hibionada, I, and Parian, A (2008) Poverty, religion and culture in the devotion to the Black Nazarene. In: L Wanak The church and poverty in Asia. Manila: OMF Literature, 108-127. Google Scholar search

Ammerman, N (2007) Introduction: Observing modern religious lives. In: N Ammerman Everyday religion: Observing modern religious lives. Oxford: Oxford University Press, 3-18. Crossref

Bautista, J and Bräunlein, PJ (2014) Ethnography as an act of witnessing: Doing fieldwork on passion rituals in the Philippines. Philippine Studies: Historical \& Ethnographic Viewpoints 62(3/4): 501-528. Crossref

Bautista, J and Lim, FKG (eds.) (2012) Christianity and the State in Asia: Complicity and Conflict. London and New York: Routledge. Crossref 
Bräunlein, PJ (2012) "We are 100\% Catholic": Philippine Passion Rituals and Some Obstacles in the Study of Non-European Christianity. Journal of Religion in Europe 5(3): 384-413. Crossref

Bulatao, J (1966) Split-level Christianity. Manila: Ateneo de Manila University Press. Google Scholar search

Chong, T (2011a) Filling the Moral Void: The Christian Right in Singapore. Journal of Contemporary Asia 41(4): 566-583. Crossref

Chong, T (2011b) Introduction. In: T Chong The AWARE saga: Civil society and public morality in Singapore. Singapore: NUS Press, 1-13. Google Scholar search

Chong, T (ed.) (2018) Pentecostal megachurches in Southeast Asia. Singapore: ISEAS. Google Scholar search

Cornelio, J (2014a) Popular religion and the turn to everyday authenticity: Reflections on the contemporary study of Philippine Catholicism. Philippine Studies: Historical and Ethnographic Viewpoints 62(3/4): 471-500. Crossref

Cornelio, J (2014b) Young people and Golden Rule Catholicism in the Philippines. In: G Vincett and E Obinna (eds.) Christianity in the Modern World: Changes and Controversies. Farnham: Ashgate, 11-36. Google Scholar search

Cornelio, J (2015) Youth and religion in East and Southeast Asia. In: J Wyn and H Cahill (eds.) Handbook of Childhood and Youth Studies. New York: Springer, 904-915. Crossref

Cornelio, J (2016) Being Catholic in the contemporary Philippines: Young people reinterpreting religion. London and New York: Routledge. Crossref

Cornelio, J (2017) Religious worlding: Christianity and the new production of space in the Philippines. In: J Koning and G Njoto-Feillard (eds.) New religiosities, modern capitalism and moral complexities in Southeast Asia. New York: Palgrave Macmillan, 169-197. Crossref

Cornelio, J (2018a) The global challenges of the Church of the future. Concilium: International Journal of Theology (4). Google Scholar search

Cornelio, J (2018b) Jesus is Lord: The indigenization of megachurch Christianity in the Philippines. In: T Chong (ed.) Pentecostal megachurches in Southeast Asia. Singapore: ISEAS, 127-155. Google Scholar search

Cox, H (2006) Thinking globally about Christianity. In: M Juergensmeyer (ed.) The Oxford Handbook of Global Religions. Oxford and NY: Oxford University Press, 245-254. Crossref

Ellingson, S (2010) New research on megachurches: Non-denominationalism and sectarianism. In: BS Turner (ed.) The new Blackwell companion to the sociology of religion. Malden, MA and Oxford: Wiley-Blackwell, 247-266. Crossref

Francisco, JM (2011) The Philippines. In: P Phan (ed.) Christianities in Asia. Malden, MA and Oxford: Wiley-Blackwell, 97-128. Crossref

Goh, RBH (2005) Christianity in Southeast Asia. Singapore: ISEAS. Google Scholar search

Gorospe, V (1966) Christian renewal of Filipino values. Philippine Studies 14(2): 191-227. Google Scholar search

Hoon, CY (2015) Contested religious space in Jakarta: Negotiating politics, capital, and ethnicity. In: P van der Veer (ed.) Handbook of religion and the Asian city: Aspiration and urbanization in the Twenty-first century. Oakland: University of California Press, 201-218. Google Scholar search 
Jenkins, P (2006) The new faces of Christianity: believing the Bible in the global south. Oxford: Oxford University Press. Google Scholar search

Jenkins, P (2011) The next Christendom: the coming of global Christianity. Oxford: Oxford University Press. Google Scholar search

Jocano, FL (1965) Conversion and the patterning of Christian experience in Malitbog, central Panay, Philippines. Philippine Sociological Review 13(2): 96-119. Google Scholar search

Koo, G (2008) Attributions of poverty: What affluent churches can do. In: L Wanak (ed.) The church and poverty in Asia. Manila: OMF Literature, 91-107. Google Scholar search

Macdonald, C (2004) Folk Catholicism and pre-Spanish religions in the Philippines. Philippine Studies 52(1): 78-93. Google Scholar search

Miller, DE (1997) Reinventing American Protestantism: Christianity in the new millennium. Berkeley: University of California Press. Google Scholar search

Ngo, TTT (2009) The "short-waved" faith: Christian broadcastings and the Protestant conversion of the Hmong in Vietnam. In: FKG Lim (ed.) Mediating piety: Technology and religion in contemporary Asia. Leiden: Brill, 139-158. Google Scholar search

Orevillo-Montenegro, M (2006) The Jesus of Asian women: Women from the margins. Maryknoll: Orbis. Google Scholar search

Pew Research (2011) Global Christianity: A report on the size and distribution of the world's Christian population. Washington, DC: Pew Research Center's Forum on Religion and Public Life. Google Scholar search

Pew Research (2014) Table: Religious Diversity Index Scores by Country. Available at: http://www.pewforum.org/2014/04/04/religious-diversity-indexscores-by-country (accessed 01 September 2016).

Phan, P (2011a) Introduction: Asian Christianity/Christianities. In: P Phan (ed.) Christianities in Asia. Malden, MA and Oxford: Wiley-Blackwell 1-6. Crossref

Phan, P (2011b) Vietnam, Cambodia, Laos, Thailand. In: P Phan (ed.) Christianities in Asia. Malden, MA and Oxford: Wiley-Blackwell, 129-147. Crossref

Prior, J (2011) Indonesia. In: P Phan (ed.) Christianities in Asia. Malden, MA and Oxford: Wiley-Blackwell, 61-75. Crossref

Sapitula, MVJ (2014) Marian piety and modernity: The Perpetual Help devotion as popular religion in the Philippines. Philippine Studies: Historical \& Ethnographic Viewpoints 62(3/4): 399-424. Crossref

Sison-Arroyo, P (2008) Seek justice: A witness of courage in a suffering world. In: L Wanak (ed.) The church and poverty in Asia. Manila: OMF Literature, 163170. Google Scholar search

Tong, CK (2008) Religious trends and issues in Singapore. In: AE Lai (ed.) Religious diversity in Singapore. Singapore: Institute of Southeast Asian Studies and Institute of Policy Studies, 28-54. Google Scholar search

Wanak, L (ed.) (2008) The church and poverty in Asia. Manila: OMF Literature. Google Scholar search

Wiegele, K (2005) Investing in miracles: El Shaddai and the transformation of popular Catholicism in the Philippines. Honolulu: University of Hawaii Press. Google Scholar search

Yip, J and Ainsworth, S (2015) "Do business till He comes": The business of housing God in Singapore megachurches. Pacific Affairs 88(2): 237-257. Crossref 